From the Department of Child Health and Department Internal Medicine

(Cardiology), Medical School, Gadjah Mada University, Jogjakarta

\title{
A Selective Study of Clinical Diphtheric Myocarditis
}

\author{
by
}

\section{A. SAMIK WAHAB, ISMANGUN and PUSTIKA SASTROAMIDJOJO}

\section{introduction}

Diphtheria is still not a rare disease in Indonesia, especially not in crowed areas (Kwari et al., 1965; Maemunah et al., 1965; Asril et al., 1968), often with high mortality in hospitals (Kwari et al., 1965; Maemunah et al., 1965; Asril et al., 1968; Sulianti, 1971).

The disease is caused by the Corynebacterium diphtheriae and is characterized by local pseudomembraneous lesions, usually on the tonsils, pharynx and adjacent tissues, rarely in the conjuctiva, vagina and skin. It causes local pain, edema and obstruction of the larynx, trachea and bronchi. Fever, prostration, cardiac damage and paralysis are constitutional symptoms. Early detection is very important although sametimes rather difficult. Usually, the diagnosis of diphtheria is made on clinical basis, and specific treatment is given without waiting for the outcome of laboratory test (Kwari et al., 1965).
Schick (1951) gives the following advice for an early diagnosis:

1. Examination of children is never complete without inspecting the throat for the detection of possible diphtheria.

2. In every case of infants with a profuse serous and somewhat bloody discharge from nose, nasal diphtheria should be considered.

3. Every spot outside the tonsils indicates a possibility of diphtheria. The same consideration has to be given to small white spots on the uvula.

4. Declining fever does not necessarily indicate an improvement of the disease. The diphtheria can progress and the general condition can become worse, inspite of the fact that the temperature somes down to normal.

Herderschee (1953) gives the following criteria for the general practitioner: 
Every membrane on the posterior pharyngeal wall, or every membrane on one tonsil or both, which occupies half of the tonsil's surface or more should be regarded as diphtheria.

Complications are caused by exotoxin entering the blood, and the severily depends on early specific treatment (Moncrieff et al., 1953; Bradford, 1969). Peripheral vascular collapse caused by myocarditis is a complication frequently found (Bradford, 1969), also in Indonesia (Asril et al., 1968). Hanafiah et al. (1965) noted diphtheria in $90 \%$ of non rheumatic myocarditis. Paralysed peripheral nerves and toxic nephritis are other complications (Person et al., 1954; Bradford, 1969).

The purpose of this study is to evaluate the prognosis of clinical diphtheric myocarditis in a certain privileged group. All cases were collected from a ward with patients coming only from families with good or fair social condition.

\section{Material and mothods}

In the period from January 1970 until to December 1971, 92 cases of diphtheria were admitted to that particular ward of the Department of Child Health Gadjah Mada University Hospital. These cases are a selective group that came to the physician or our hospital in the initial stage of illness. Diagnosis of diphtheria was based on clinical findings characterized by:
1. Fever of two days or more,

2. Pseudomembraneous lesions, or

3. Local spots, usually on the tonsil, pharynx and adjacent tissuea which did not change or extend after one or more antibiotic injections and

4. Confirmed by positive direct smear.

All cases belonged to the tonsil/ pharynx type, except one which was combined with nasal and suspected conjunctival diphtheria (although conjunctival secretion smear was negative for diphtheria).

ECG examinations were made only when myocarditis was suspected such as in cases with soft and impure first sound, accentuated second sound at the apex; gallop rhythm, premature beats, bradycardia, tachycardia or cardiac failure (Person et al., 1954; Friedberg, 1957; Kwari et al., 1955).

ECG changes as ST segment depression, $\mathrm{T}$ wave changes, Right and left Bundle Branch Block, lengthening of PR, incomplete and complete A-V block tachycardia, atrium fibrillation, atrium flutter and lengthening of QT were looked for (Friedberg, 1957; Kwari, 1965; Maemunah, 1965; Goldman, 1967).

\section{Discussion and results}

Brodford (1969) noted a mortality rate of diphtheria

of the disease

ment was 
day of the disease the mortality rate was about $0,3 \%$, on the third day $4 \%$ and on subsequent days $25 \%$. The mortality rate was highest among young infants (Bradford, 1969), according to Kwari et al. (1965) in the age group of two years and according to Asril et al. (1968) in the group of between $0-2$ years.

During January 1970 to December 1971, 92 selected cases of diphtheria were admitted consisting of 51 girls and 41 boys, with ages ranging from
2 months to 11 years. The mortality rate of our cases was zero.

All of our cases belonged to the tonsil and pharynx type, except one case which had a combination with nasal diphtheria and suspected conjunctival diphtheria (although a swab of conjunctival secretion was negative).

ECG studies were made on 47 patients with suspected myocarditis, with the following results:

\begin{tabular}{l|r|r|r|c}
\hline Years. & Normal ECG & Abnormal ECG & $\%$ & Total \\
\hline 1970 & 7 & 13 & \pm 65 & 20 \\
1971 & 16 & 11 & 51 & 27 \\
\hline & 23 & 24 & 40 & 47 \\
\hline
\end{tabular}

Result of ECG examinations:

ECG $c h$ a $n$ g $s$ : C a s e s :

1. Myocardial damage: (ST segment depression/ without $\mathrm{T}$ wave changes)

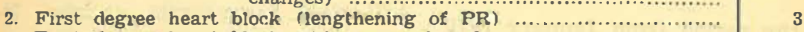

3. First degree heart block with myocardial damage ....................... 2

4. Firs degree heart block with sinus tachycardia ........................

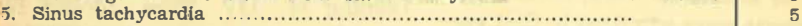

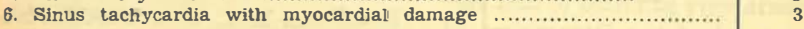

According to Fiedberg (1957) lowed by $\mathrm{T}$ wave changes on two the earliest ECG changes of myocar- leads or more. Although conduction ditis are ST segment depression, fol- disturbances are much less frequent, 
they are more distinctive of diphtheritic myocarditis and denote a serious prognosis.

First degree heart block and more severe grade of partial heart block has often been found. Right and left bundle branch block, complete A-V block are serious complications. Kwari et al. (1965) found $66,6 \%$ fatality with $\mathrm{LBBB}, 40 \%$ died with RBBB, and $100 \%$ with complete A-V block.

Other ECG changes are sinus tachycardia/sinus bradycardia, transient extra systoles, and nodal rhythm, paroxysmal tachycardia, atrium fibrillation, atrium-flutter and lengthening of QT.

Kwari et al. (1965) found ECG changes in $19,5 \%$ of 466 cases of diphtheria with a mortality rate of $40 \%$. This rate was ten times that of patients with normal ECG $(4 \%)$. ECG changes were found as follows:

$\mathrm{T}$ wave changes $\pm 63,7 \%$, LBBB $\pm 13,2 \%, \mathrm{RBBB} \pm 5,4 \%$. Total $\mathrm{A}-\mathrm{V}$ block $16,2 \%$ and ventricular fibrillation $\pm 1,1 \%$.
Maemunah et al. (1965) found 18 myocarditis cases out of 92 cases of diphtheria and fatality rate was $55,5 \%$. Changes in ECG were: LBBB in 4 cases, $R B B B$ in 1 cases, first degree heart block in 1 case, third degree heart block in 1 case, myocardial damage in 15 cases, arrhytmia such as sinus tachycardia in 6 cases, sinus bradycardia in 2 cases and nodal rhythm in 2 cases.

Sinus tachycardia is a sign of peripheral collapse. Kwari et al. (1965) often saw patients with diphtheria dying in shock syndrome without obvious ECG changes, but only sinus tachycardia, slight ST depression or low $\mathrm{T}$ waves.

The cardiac rate in infants is rapid and subject to wide fluctuation. The average rate, ranging from 120 140 beats per minute with an increase during crying and activity, and decrease during sleep. As the child grows older the average pulse rate becomes slower. Hereby follows a table compiled from Kaplan (1969).

\begin{tabular}{c|c}
\hline Age & Maximal normal rhythm \\
\hline Newborn & 170 \\
2 years & 160 \\
4 years & 130 \\
6 years & 115 \\
8 years & 110 \\
10 years & 110 \\
\hline
\end{tabular}




\begin{tabular}{c|cc}
\hline \multicolumn{1}{c|}{ Age } & \multicolumn{2}{|c}{ Maximal normal rhythm } \\
\hline & & male \\
12 years & 110 & 105 \\
14 years & 105 & 100 \\
16 years & 100 & 95 \\
\hline
\end{tabular}

Sinus tachycardia was diagnosed in our cases when frequency rate was more than the maximum normal rhythm.

Immunization has resulted in decrease of the mortality rate of diphtheria. In USA the incidence of diph. theria decreased rapidly after intensifying active immunization.
The number of reported cases decreased from 1580 in 1956 to 168 in 1965 , and the number of deaths for these years decreased from 103 to 16 (Bradford, 1969). Most of the diphtheria cases of Maemunah et al. 1965) and Asril et al. (1968) were not immunized, fatality rate and ro, 1956 natural immunity is high Influence of immunization in our cases is shown in the following table:

\begin{tabular}{|c|c|c|c|}
\hline & Cases & Immunized (DPT) & Non-Immunized \\
\hline Abormal ECG : & 24 & 12 & 11 \\
\hline Normal ECG : & 23 & 6 & 18 \\
\hline & 47 & 18 & 29 \\
\hline
\end{tabular}

Abnormal ECGs were lower in immunzed cases than in non-immunized ones. According to Wallgren (1969) immunization gives an effective protection to children until 5 years or more. On the other hand, Henderson et al. (1971) noted effective protection for a decade or more, and protection against a fatal outcome for an even longer period.

Natural immunity in South East Asia has somewhat a similar pat- tern, i.e. about $30 \%$ at one year of age, and $75 \%$ at 5 years. In Indonesia according to Sukamto and Tesch (1939-1941) (cited from Pusponegoro, 1956) natural immunity is high in the first trimester, and in $\mathbf{5}$ to $\mathbf{1 2}$ years of age reches $80-90 \%$.

Natural immunity has been found high, i.e. $70 \%$ at the age of 5 months and at pre-school age (Munginah, 1971).

Abnormal ECG according to age: 


\begin{tabular}{c|c|c}
\hline Age & Normal ECG & Abnornal ECG \\
\hline $0-2$ years & 4 & 7 \\
$2-4$ years & 4 & 4 \\
$4-6$ years & 5 & 6 \\
$6-8$ years & 3 & 6 \\
$8-10$ years & 4 & 1 \\
$10-12$ years & 3 & - \\
\hline
\end{tabular}

\section{Conclussion}

Low mortality rates (zero) and very mild ECG abnormality changes are found in selective cases of diphtheria among children belonging to families with good or fair socio-economic condition.

\section{Summary}

Ninety-two selected cases of diphtheria coming from good to fair socio-economic background were admited to a special ward of the Department of Child Health, Medical School, Gadjah Mada University,
Jogjakarta, during the years 1970 and 1971.

In 47 out of the 92 cases, myocarditis was clinically suspected, and further examined by ECG.

The results were 24 cases $( \pm 51 \%)$ with abnormal ECG, and 23 cases ( $\pm 49 \%$ ) with normal ECG.

ECG abnormalities were recorded as sinus tachycardia, lengthening of PR, ST segment depression with or without $T$ wave changes and considered as very slight.

Effects of immunization has been discussed.

\section{REFERENCES}

1. ASRIL, A., MAEMUNAH B. AFFANDI, HANAFIAH, A. and SUTEDJO: A 3-year clinical evaluation of diphtheria. Paediat. Indon. 9: 171 (1969).

2. BRADFORD, W.L.: In Nelson's Text book of Paediatrics, 9th ed. Asia ed. (Igaku Shoin, Tokyo 1969).

3. FRIEDBERG, C.K. : Diseases of the heart 2nd ed. (Saunders, Philadelphia/ London 1957).

4. GOLDMAN, M.J. : Principles of clinical Electrocardiography, (Lange Medical Publ., Los Altos California 1964).

5. HANAFIAH, A. LIEM THIAN KO and RANTI, I.S.F. : Heart disease in infancy and childhood in Jakarta. Paediat. Indon. 5 : 952 (1965).

6. HENDERSON, D.A. LABUSQUIRE, R, NICHOLSON, Cl., REY M., RISTORI, C., DOWN, P.J.N., SUIIANTI SAROSO, J., MILLAR, J.D.: Immunization, 2nd Nat. Congr. Paediat., Bandung 1971.

7. HENDERSCHEE, D. : cit. by Kwari, S. (see Ref. K.).

8. KWARI, S., YAP KHEE NIO and THE SOEY LIANG: A clinical study of diphtheria with special reference to cardiac complications. Paediat. Indon. 5: 928 (1965). 
9. KAPLAN, S. : In Nelson's Text book of Pediatrics, 9th ed. Asia ed. (Igaku Shoin, Tokyo 1969).

10. MAEMUNAH, A., KARJOMANGGOLO, W.T., RANTI, I.S.F. and WIDODO TALOGO, K. : Diphtheria in Childhood in Djakarta. Paediat. Indon. 5: 942 (1965).

11. MONCRIEFF, A., EVANS, P. : Diseases of Children; 5 th ed., Vol. 2 (Edward Amold, London 1953).

12. MUNGiNAH, P.A. : Personal Communication (1971).

13. PUSPONEGORO, SUDJONO D. : Prophylaxis and Immunization in Children.
Berita Kementerian Kesehatan No. 4 : 56 (1965).

14. PARSON, L., BARLING, S.: Diseases of Infancy and Childhood, 2nd ed. (Oxford University Press, London/ New York/Toronto 1954).

15. SULTANTI, SAROSO J. : Immunization progammes in Inonesia. Paediat. Indon $12: 403$ (1972).

16. SCHICK, BELA: In Brennemann's Practice of Pediatrics, Vol. 4(Prior Company, Hagerstown Maryland 1952).

17. WALLGREN, A. : Vaccination in Childhood. Triangle 4: 44 (1959). 